\title{
Peran Komisi Pemilihan Umum Provinsi DKI Jakarta Dalam Meningkatkan Partisipasi Politik Masyarakat Dalam Pilkada Jakarta 2017
}

\author{
Faiz Aprila Fiscana*
}

\begin{abstract}
Abstrak
Komisi Pemilihan Umum Provinsi Daerah Khusus Ibukota Jakarta adalah sebagai penyelenggara Pemilu yang mengajarkan kepada masyarakat bagaimana terlibat dalam proses pengambilan keputusan politik dengan cara memberikan suara kepada partai politik tertentu yang menjadi pilihannya. Rumusan masalah dalam penelitian yaitu peran Komisi Pemilihan Umum Provinsi DKI Jakarta dalam meningkatkan partisipasi pemilih pada pilkada DKI Jakarta tahun 2017. Tujuan penelitian yaitu untuk menganalisis peran Komisi Pemilihan Umum Provinsi DKI Jakarta dalam Meningkatkan Partisipasi Pemilih pada Pilkada DKI Jakarta 2017. Kegunaan penelitian yaitu dapat memberikan informasi kepada masyarakat peran Komisi Pemilihan Umum Provinsi DKI Jakarta. Metode penelitian yang digunakan yuridis normatif. Hasil penelitian menggambarkan peran Komisi Pemilihan Umum Provinsi DKI Jakarta dalam meningkatkan partisipasi pemilih masyarakat pada Pilkada DKI Jakarta 2017 yaitu melakukan sosialisasi kepada masyarakat dengan penyebaran informasi melalui alat-alat peraga seperti baliho, poster, pamflet, pin, spanduk, stiker pada mobil/motor/rumah dan melalui media massa seperti radio, dan surat kabar. Kesimpulan yaitu peran Komisi Pemilihan Umum Provinsi DKI Jakarta dirasa cukup efektif telah bekerja keras untuk meningkatkan partisipasi jumlah pemilih setiap perhelatan Pilkada yang berlangsung.
\end{abstract}

Kata Kunci : Peran Komisi Pemilihan Umum, Partisipasi Politik, Pilkada

\section{The role of the DKI Jakarta Provincial Election Commission in Increasing Community Political Participation In the 2017 Jakarta Election}

\begin{abstract}
The General Election Commission of the Special Capital Province of Jakarta is the organizer of the General Election which teaches the public how to be involved in the political decision-making process by voting for certain political parties of their choice. The formulation of the problem in this research is the role of the DKI Jakarta Provincial Election Commission in increasing voter participation in the DKI Jakarta elections in 2017. The research objective is to analyze the role of the DKI Jakarta Provincial Election Commission in Increasing Voter Participation in the 2017 DKI Jakarta Election. information to the public the role of the DKI Jakarta Provincial Election Commission. The research method used is normative
\end{abstract}

*E-mail: faizfiscana@gmail.com 
juridical. The results of the study illustrate the role of the DKI Jakarta Provincial Election Commission in increasing public voter participation in the 2017 DKI Jakarta Regional Election, namely to disseminate information to the public by disseminating information through props such as billboards, posters, pamphlets, pins, banners, stickers on cars / motorbikes / home and through mass media such as radio and newspapers. The conclusion is that the role of the DKI Jakarta Provincial Election Commission is deemed effective enough to have worked hard to increase voter turnout per election event that took place.

Kata Kunci : The role of the electoral commission, Political Participation, Regional head election

\section{Pendahuluan}

Komisi Pemilihan Umum yang selanjutnya disingkat KPU adalah lembaga Penyelenggara Pemilu yang bersifat nasional, tetap, dan mandiri dalam melaksanakan pemilu. Agar pemilu benar-benar menghasilkan pemerintahan yang demokratis, maka pemilu sudah seharusnya diselenggarakan oleh suatu lembaga negara yang independen dan tidak memihak. Oleh karena itu, KPU sebagai lembaga penyelenggara pemilu di Indonesia harus selalu berpegang pada peraturan perundang undangan yang ada, kode etik dan tata tertib KPU. Tugas dan wewenang KPU dalam menyelenggarakan pemilu tidak semata-mata berhubungan dengan partai-partai peserta pemilu, tetapi juga harus dengan masyarakat sebagai pemberi suara dalam pemilu.

Untuk menjalankan roda kegiatan KPU, lembaga tersebut dibantu Sekretariat Jendral (Setjen). Secara struktural KPU terdiri dari KPU Pusat dan KPU Daerah. KPU pusat berkedudukan di Jakarta, KPU Provinsi berkedudukan di ibu kota provinsi, KPU Kabupaten/Kota berkedudukan di ibu kota/kabupaten. Dalam melaksanakan tugasnya, KPU dibantu oleh Pantia Pemilihan Kecamatan (PPK) yang berkedudukan di setiap kecamatan, dan Panitia Pemungutan Suara (PPS) yang berkedudukan di setiap desa atau kelurahan, setelah terbentuk, PPS membentuk kelompok Penyelenggaraan Pemungutan suara.

Komisi Pemilihan Umum Provinsi Daerah Khusus Ibukota Jakarta, selanjutnya disingkat KPU Provinsi DKI Jakarta adalah sebagai lembaga penyelenggara pemilihan umum sebagaimana dimaksud dalam Undang-undang 
penyelenggara pemilihan umum yang diberikan tugas menyelenggarakan Pemilihan Gubernur dan Wakil Gubernur berdasarkan ketetentuan yang diatur dalam Undang-Undang Republik Indonesa Nomor 7 Tahun 2017 tentang Pemilihan Umum, Undang Undang Nomor 1 Tahun 2015 tentang Pilkada, dan Undang Undang RI Nomor 15 Tahun 2011 Tentang Penyelenggara Pemilu.

Kegiatan pemilihan umum (Pemilu) merupakan salah satu kegiatan politik yang paling banyak menarik perhatian dan keterlibatan masyarakat sehingga pemilu menjadi momen pendidikan politik yang sangat penting dalam rangka mendewasakan warga negara. Pemilu mengajarkan kepada masyarakat bagaimana terlibat dalam proses pengambilan keputusan politik dengan cara memberikan suara kepada partai politik tertentu yang menjadi pilihannya.

Pemilihan Umum merupakan pranata terpenting dalam tiap negara demokrasi, terlebih lagi bagi negara yang berbentuk Republik seperti Indonesia. Pranata itu berfungsi untuk memenuhi tiga prinsip pokok demokrasi, yaitu kedaulatan rakyat, keabsahan pemerintahan, dan pergantian pemerintahan secara teratur. Ketiga prinsip tersebut bertujuan untuk menjamin terjaga dan terlaksananya cita-cita kemerdekaan, mencegah bercokolnya kepentingan tertentudi dalam tubuh tertentu di dalam kepentingan tertentu di dalam pemerintahan, atau digantikannya kedaulatan rakyat menjadi kedaulatan penguasa. (Mukhtie Fadjar, 2013 : 1)

Partisipasi politik dalam negara demokrasi merupakan indikator implementasi penyelenggaraan kekuasaaan negara tertinggi yang absah oleh rakyat (kedaulatan rakyat), yang dimanifestasikan keterlibatan mereka dalam pesta demokrasi (Pemilu). Semakin tinggi tingkat partisipasi politik mengindikasikan bahwa rakyat mengikuti dan memahami serta melibatkan diri dalam kegiatan kenegaraan. Sebaliknya tingkat partisipasi politik yang rendah pada umumnya mengindikasikan bahwa rakyat kurang menaruh apresiasi atau minat terhadap masalah atau kegiatan kenegaraan. Rendahnya tingkat partisipasi politik rakyat direfleksikan dalam sikap golongan putih (golput) dalam pemilu.(Soebagio, $2008: 82$ ) 
Partisipasi politik merupakan aspek penting dalam sebuah tatanan negara demokrasi, sekaligus merupakan ciri khas adanya modernisasi politik. Secara umum dalam masyarakat tradisional yang sifat kepemimpinan politiknya lebih ditentukan oleh segolongan elit penguasa, keterlibatan warga negara dalam ikut serta memengaruhi pengambilan keputusan, dan memengaruhi kehidupan bangsa relatif yang sangat kecil. Warga negara yang hanya terdiri dari masyarakat sederhana cenderung kurang di perhitungkan dalam proses-proses politik.(Sudjino Sastroatmodjo, 1955 : 56)

Partisipasi Politik masyarakat secara umum dapat dikategorikan dalam beberapa bentuk sebagai berikut : (Mas'oed, Mochtar dan Mac Andrews. 2005 : 225)

\section{a. Electroral activity}

Yaitu segala bentuk kegiatan yang secara langsung atau tidak langsung berkaitan dengan pemilihan. Termasuk dalam kategori ini adalah ikut serta dalam memberikan sumbangan untuk kampanye, menjadi sukarelawan dalam kegiatan kampanye, ikut mengambil bagian dalam kampanye atau rally politik sebuah partai, mengajak seseorang untuk mendukung dan memilih sebuah partai atau calon pemimpin, memberikan suara dalam pemilihan, mengawasi pemberian dan penghitungan suara, menilai caloncalon yang diajukan dan lain-lainnya.

b. Lobbying

Yaitu tindakan dari seseorang atau sekelompok orang untuk menghubungi pejabat pemerintah ataupun tokoh politik dengan tujuan untuk mempengaruhinya menyangkut masalah tertentu.

c. Organizational activity

Yaitu keterlibatan warga masyarakat ke dalam organisasi sosial dan politik, apakah ia sebagai pemimpin, aktivis, atau sebagai anggota biasa.

d. Contacting

Yaitu partisipasi yang dilakukan oleh masyarakat dengan secara langsung pejabat pemerintah atau tokoh politik, baik dilakukan secara individu maupun kelompok orang yang kecil jumlahnya. Biasanya, dengan bentuk 
partisipasi seperti ini akan mendatangkan manfaat bagi yang orang yang melakukannya.

e. Violance

Yaitu dengan cara-cara kekerasan untuk mempengaruhi pemerintah, yaitu dengan cara kekerasan, pengacauan dan pengrusakan.

Partisipasi merupakan hal terpenting dalam kehidupan bermasyarakat, karena dengan berpartisipasi, masyarakat bisa mengambil bagian dalam proses pemilihan baik secara langsung maupun tidak langsung.

Pilkada merupakan momentum yang cukup tepat munculnya berbagai varian preferensi pemilih yang menjadi faktor dominan dalam melakukan tindakan atau perilaku politiknya. Terdapat beberapa alasan yang melatarbelakangi saya mengambil tema tentang partisipasi politik dalam Pilkada DKI Jakarta, antara lain adalah adanya peningkatan partisipasi politik dalam pilkada tahun 2017 sebesar 12\% bila dibandingkan dengan pilkada tahun 2007, pada tahun 2017 partisipasi pemilih naik drastis hingga menyentuh angka 77\% jauh jika dibandingkan dengan Pilkada 2007 sebesar 65\% dan Pilkada 2012 sebesar 64\%.(Website Resmi KPU)

Diketahui, di masing-masing wilayah di Jakarta, terdapat angka partisipasi yang variatif. Partisipasi paling tinggi terjadi di Kabupaten Kepulauan Seribu dengan pemilih yang menggunakan haknya sebesar $81 \%$, kemudian Jakarta Timur $78 \%$, Jakarta Utara $77 \%$, Jakarta Barat sebanyak $75 \%$, dan Jakarta Pusat sebesar $74 \%$.

Alasan lainnya karena dari 100\% data pemilih kenapa hanya sebagian atau $3 / 4$ dari pemilih saja yang menggunakan hak pilihnya, apakah ini dilandasi faktor golput semata atau ada faktor-faktor diluar itu, ini lah yang saya ingin teliti lebih dalam. Dari 7.170.001 Pemilih hanya 5.572.465 suara jumlah pemilih yang menggunakan hak pilihnya, itu berarti ada sekitar 1.597.536 suara yang tidak menggunakan hak pilihnya.

Ini yang membuat penulis tertarik ingin meneliti peran Komisi Pemilihan Umum DKI Jakarta dalam meningkatkan partisipasi pemilih masyarakat di DKI Jakarta yang tingkat partisipasinya masih rendah. Diharapkan nantinya pada 
Pemilu dan Pilkada yang akan datang ini, baik itu pileg dan pilpres ataupun Pilkada Serentak bisa berjalan dengan lancar dan kondusif dari masalah-masalah yang mempunyai kontribusi besar terhadap munculnya konflik dalam setiap tahapan Pilkada. Masalah lain yang patut diperhatikan adalah kacaunya Daftar Pemilih Tetap (DPT) ditambah dengan kurangnya partisipasi masyarakat dalam pemilihan sehingga banyak yang tidak ikut memilih atau bisa dikatakan Golput.

Berdasarkan latar belakang masalah yang telah diindentifikasi dan ditegaskan dalam pembatasan masalah maka dapat dirumuskan masalah yaitu : bagaimana peran KPU Provinsi DKI Jakarta dalam meningkatkan partisipasi politik masyarakat di DKI Jakarta dalam Pilkada DKI Jakarta 2017?

\section{Pembahasan}

\section{A. Peran KPU Provinsi Jakarta Dalam Meningkatkan Partispasi Pemilih}

Salah satu di antara elemen dan indikator yang paling mendasar dari keberhasilan dan kualitas pelaksanaan penyelenggaraan pemilu yang demokratis adalah adanya keterlibatan masyarakat secara aktif dalam proses berjalannya tahapan-tahapan pemilu, khususnya dalam hal pengawasan atau pemantauan proses pemilu.

Partisipasi politik adalah kegiatan seseorang atau sekelompok orang untuk ikut secara aktif dalam kehidupan politik, antara lain dengan jalan memilih pimpinan negara dan secara langsung atau tidak langsung memengaruhi kebijakan pemerintah. Kegiatan itu mencakup tindakan seperti memberikan suara dalam pemilihan umum, menghadiri rapat umum, mengadakan hubungan (contacting) atau lobbying dengan pejabat pemerintah atau anggota parlemen, menjadi anggota partai atau salah satu gerakan sosial dengan direct action-nya, dan sebagainya. (Miriam Budiardjo, 2008 : 1)

Keterlibatan atau partisipasi rakyat adalah hal yang sangat mendasar dalam demokrasi, karena demokrasi tidak hanya berkaitan dengan tujuan sebuah ketetapan yang dihasilkan oleh suatu pemerintahan, tetapi juga berkaitan dengan 
seluruh proses dalam membuat ketetapan itu sendiri. Partisipasi masyarakat bertujuan untuk :

1) Menyebarluaskan informasi mengenai tahapan, jadwal dan program pemilihan

2) Meningkatkan pengetahuan, pemahaman dan kesadaran masyarakat tentang hak dan kewajiban dalam pemilihan

3) Meningkatkan partisipasi pemilih dalam Pemilihan

Menurut Joko J. Prihatmoko (2003) tujuan dari sosialisasi adalah untuk membentuk dan menumbuhkan kepribadian politik dan kesadaran politik, serta partisipasi politik rakyat. Pendidikan politik menjadi sangat penting untuk menumbuhkan budaya demokratis di masyarakat. Pendidikan politik memang tugas seluruh masyarakat, termasuk lembaga pendidikan dan keluarga.

Sedangkan menurut Arbi Sanit (1997), partisipasi politik adalah peran serta masyarakat secara kolektif di dalam proses penentuan pemimpin, pembuatan kebijaksanaan publik, dan pengawasan proses pemerintahan. Pemilu menjadi instrumen sangat penting dalam mendorong keterlibatan masyarakat dalam pengambilan keputusan tentang siapa yang berhak menjalankan organisasi yaitu negara Indonesia, baik di dalam lembaga legislative ataupun lembaga eksekutif.

Upaya-upaya yang dilakukan Komisi Pemilihan Umum Provinsi DKI Jakarta dalam meningkatkan partisipasi masyarakat pada Pilkada 2017 sebagai berikut:

\section{Melakukan Sosialisasi Kepada Masyarakat}

Sosialisasi politik, khususnya tentang pemilu sangat penting dilakukan agar penyelenggaraan Pemilu dari waktu ke waktu semakin berkualitas. Bagaimanapun juga pemilu telah menjadi harga mati sebagai mekanisme untuk menghasilkan pemerintahan yang demokratis. Sosialisasi politik yang berhasil dengan baik dengan sendirinya akan mendukung pemilu menjadi lebih baik. Pengalaman pemilu-pemilu sebelumnya ataupun pemilu Kepala Daerah di berbagai daerah di Indonesia harus menjadi pelajaran tentang 
bagaimana harus menyelenggarkan pemilu dengan lebih baik. (Yusuf, 2010 : 2-4)

Jadi sasaran Sosialisasi pemilihan yang dilakukan oleh Komisi Pemilihan Umum Provinsi DKI Jakarta dalam Pilkada DKI Jakarta 2017 adalah :(Yusuf, $2010: 2-4)$

a. Masyarakat umum

b. Pemilih pemula meliputi remaja, pemuda, pelajar dan mahasiswa

c. Tokoh masyarakat dan/atau pemuka adat

d. Kelompok media massa

e. Partai politik

f. Pengawas, Pemantau Pemilihan Dalam Negeri dan Pemantau Pemilihan Asing

g. Organisasi Kemasyarakatan

h. Organisasi Keagamaan

i. Kelompok adat

j. Instansi pemerintah

k. Pemilih dengan kebutuhan khusus, mencakup penyandang disabilitas, masyarakat di wilayah perbatasan atau terpencil, penghuni lembaga permasyarakatan, pasien dan pekerja rumah sakit, pekerja tambang lepas pantai, perkebunan, dan kelompok lain yang terpinggirkan

1. Kelompok perempuan

m. Komunitas masyarakat dalam bentuk lain.

Berbagai aspek yang harus disosialisasikan kepada masyarakat pemilih berkaitan dengan Pemilu di antaranya yaitu: manfaat pemilu, nama-nama peserta pemilu, ajakan untuk memberikan suara nanti pada saat pemungutan suara, tata cara pemilu, jadwal pemilu, khususnya pada tahap kampanye, tata cara pencoblosan, jadwal pemungutan suara dan pengumuman hasil penghitungan suara. 


\section{Menyebarkan Informasi Melalui Alat-alat Peraga}

Kata "Alat Peraga" diperoleh dari dua kata alat dan peraga. Kata utamanya adalah peraga yang artinya bertugas "meragakan" atau membuat bentuk "raga" atau bentuk "fisik" dari suatu arti/pengertian yang dijelaskan. Bentuk fisik itu dapat berbentuk benda nyatanya atau benda tiruan dalam bentuk model atau dalam bentuk gambar visual/audio visual.(Kamus Besar Bahasa Indonesia)

Berdasarkan Keputusan KPU Provinsi DKI Jakarta Nomor 22/Kpts/KPUProv-010/Tahun 2016, Alat Peraga dalam sosialisasi yang dilakukan olek KPU Provinsi DKI Jakarta adalah : Spanduk, Banner, Baliho, Billboard / Videotron, dan Umbul-Umbul.

Dalam alat peraga ini, KPU Provinsi mengatur soal alat peraga kampanye Pilkada 2018. Salah satu yang diatur KPU Provinsi adalah desain dan materi alat kampanye. Aturan mengenai alat peraga kampanye adalah :

1) KPU Provinsi/KIP Aceh atau KPU/KIP Kabupaten/Kota memfasilitasi pembuatan dan pemasangan Alat Peraga Kampanye sebagaimana dimaksud dalam Pasal 5 ayat (3) huruf c.

2) Alat Peraga Kampanye sebagaimana dimaksud pada ayat (1) meliputi:

a) baliho/billboard/videotron paling besar ukuran 4 (empat) meter $\mathrm{x} 7$ (tujuh) meter, paling banyak 5 (lima) buah setiap Pasangan Calon untuk setiap kabupaten/kota;

b) umbul-umbul paling besar ukuran 5 (lima) meter x 1,15 (satu koma lima belas) meter, paling banyak 20 (dua puluh) buah setiap Pasangan Calon untuk setiap kecamatan; dan/atau

c) spanduk paling besar ukuran 1,5 (satu koma lima) meter x 7 (tujuh) meter, paling banyak 2 (dua) buah setiap Pasangan Calon untuk setiap desa atau sebutan lain/kelurahan. (Peraturan KPU Nomor 4 Tahun 2017 Tentang Kampanye, Pasal 28)

Sedangkan terkait ketentuan Desain dan materi alat peraga ditentukan Oleh KPU, yaitu : 
1) Desain dan materi Alat Peraga Kampanye sebagaimana dimaksud dalam Pasal 28 ayat (1) dan ayat (2) dibuat dan dibiayai oleh Partai Politik atau Gabungan Partai Politik, Pasangan Calon dan/atau Tim Kampanye sesuai dengan ukuran yang telah ditentukan oleh KPU Provinsi/KIP Aceh atau KPU/KIP Kabupaten/Kota.

2) Desain dan materi sebagaimana dimaksud pada ayat (1) dapat memuat nama, nomor, visi, misi, program, foto Pasangan Calon, tanda gambar Partai Politik atau Gabungan Partai Poitik dan/atau foto pengurus Partai Politik atau Gabungan Partai Politik. (Peraturan KPU Nomor 4 Tahun 2017 Tentang Kampanye, Pasal 28)

\section{Sosialisasi Melalui Media Massa : Cetak Maupun Elektronik}

Media massa merupakan sarana penyampaian komunikasi dan informasi yang melakukan penyebaran informasi secara massal dan dapat diakses oleh masyarakat secara luas (Apriadi Tamburaka, $2001: 21$ )

Media merupakan lembaga yang bertanggung jawab memberikan pengawasan terhadap penyelenggaraan pemilu yang bersih, jujur, adil, transparan, dan profesional. Melalui pemberitaan yang dilakukan oleh media massa, masyarakat akan memperoleh gambaran umum terkait penyelenggaraan pilkada. Termasuk menginformasikan rekam jejak caloncalon gubernur dan wakil gubernur DKI Jakarta.

Komisi Pemilihan Umum DKI Jakarta sudah menandatangani nota kesepahaman dengan semua stasiun televisi nasional terkait sosialisasi Pilkada DKI Jakarta 2017. Anggota KPU DKI Dahlia Umar mengatakan perjanjian kerja sama itu juga mencantumkan perjanjian semua stasiun televisi berimbang dalam memberitakan pasangan cagub dan cawagub DKI.

Komisi Pemilihan Umum Provinsi DKI Jakarta tidak mengatur media massa, KPU hanya ingin ada keseimbangan sosialisasi bagi pasangan calon gubernur dan wakil gubernur di DKI Jakarta. 
KPU DKI akan membiayai kampanye semua pasangan calon termasuk dalam hal beriklan di media massa. Semua pasangan calon mendapatkan porsi beriklan yang sama.

\section{Komunikasi Tatap Muka}

Komunikasi tatap muka dapat berupa : Diskusi, Seminar, Workshop / lokakarya, Rapat kerja, Pelatihan, Ceramah, Simulasi, Door to door, dan Metode tatap muka lainnya.

Tujuan kegiatan tersebut adalah memberikan informasi bagi mereka untuk dapat menggunakan hak pilihnya nanti pada tanggal 15 Februari 2017 dan meningkatkan partisipasi pemilih nanti pada Pilkada Gubernur dan Wakil Gubernur Tahun 2017.

Sosialisasi politik, khususnya tentang pemilu sangat penting dilakukan agar penyelenggaraan Pemilu dari waktu ke waktu semakin berkualitas. Bagaimanapun juga pemilu telah menjadi harga mati sebagai mekanisme untuk menghasilkan pemerintahan yang demokratis. Sosialisasi politik yang berhasil dengan baik dengan sendirinya akan mendukung pemilu menjadi lebih baik. (Yusuf, $2010: 2-4$ )

\section{B. Faktor Timbulnya Partisipasi Politik}

Ada beberapa faktor yang dapat menimbulkan meningkatnya tingkat partisipasi politik pemilih di DKI Jakarta dalam Pemilihan Umum Kepala Daerah 2017, yaitu :

\section{Faktor Pencalonan}

Proses pendaftaran calon gubernur dan wakil gubernur untuk mengikuti Pilkada DKI tahun 2017 telah berakhir. Tiga pasang calon secara resmi mendaftar ke kantor KPU DKI mulai dari tanggal 21-23 September 2016. Mereka terdiri dari :
a. Basuki Tjahaja Purnama - Djarot Saiful Hidayat
b. Agus Harimurti Yudhoyono - Sylviana Murni
c. Anies Rasyid Baswedan - Sandiaga Uno 
Pasangan Basuki - Djarot didukung oleh 4 Partai Politik Nasional, yaitu Partai Demokrasi Indonesia Perjuangan (PDIP), Partai Golongan Rakyat (Golkar), Partai Nasional Demokrat (NasDem) dn Partai Hati Nurani Rakyat (Hanura). Hal ini cukup mengejutkan kaena sebelumnya PDIP dan sejumlah partai politik bersikeras untuk melawan basuki - Djarot untuk maju menjadi DKI 1. (Website News Detik) Namun Koalisi itu tidak terpecah di tengah jalan dikarenakan tak sejalannya Partai Politik itu dalam menentukan siapa Calon Gubernur yang akan diusung.

Pasangan kedua yang mendaftar di KPU Provinsi DKI Jakarta ialah Agus Harimurti Yudhoyono dan Sylviana Murni, pasangan ini diusung oleh 4 Partai Politik nasional, yaitu Partai Demokrat, Partai Kebangkitan Bangsa (PKB), Partai Persatuan Pembangunan (PPP) dan Partai Amanat Nasional (PAN).

Agus Harimurti Yudhoyono adalah Putra pertama dari Presiden Republik Indonesia ke-6 Susilo Bambang Yudhoyono, Agus sendiri adalah Tentara Nasional Indonesia (TNI) yang rela melepas almamaternya itu demi ikut dalam kontestansi Pilkada DKI Jakarta 2017. (Website Wikipedia Agus Harimurti Yudhoyono)

Yang terakhir ialah pasangan Anies Baswedan dan Sandiaga Uno, pasangan ini hanya didukung oleh dua Partai Politik Nasional, yaitu Partai Gerakan Indonesia Raya (Gerindra) dan Partai Keadilan Sosial (PKS), kedua partai tersebut membuat poros baru, yaitu poros ketiga karena koalisi dengan poros Cikeas (Partai Demokrat, PKB, PPP dan PAN) tidak menemui titik temu dalam menentukan sikap.

Anies Baswedan pernah menjabat sebagai Menteri Pendidikan dan Kebudayaan Republik Indonesia untuk Kabinet Kerja sejak 26 Oktober 2014 sampai 27 Juli 2016. Anies merupakan cucu dari pejuang kemerdekaan Abdurrahman Baswedan. Ia menginisiasi gerakan Indonesia Mengajar dan menjadi rektor termuda yang pernah dilantik oleh sebuah perguruan tinggi di Indonesia pada tahun 2007 saat menjadi Rektor 
Universitas Paramadina pada usia 38 tahun. (Website Wikipedia Anies baswedan)

Sedangkan Wakilnya Sandiaga Uno ialah adalah seorang pengusaha, bersama rekannya ia mendirikan sebuah perusahaan di bidang keuangan, PT Saratoga Advisor. Usaha tersebut terbukti sukses dan telah mengambil alih beberapa perusahaan lain. (Website Kompas) Pada tahun 2009, ia tercatat sebagai orang terkaya urutan ke-29 di Indonesia menurut majalah Forbes. (Website Detik Finance) Tahun 2011, Forbes kembali merilis daftar orang terkaya di Indonesia. Ia menduduki peringkat ke-37 dengan total kekayaan US\$ 660 juta.

Dari ketiga paslon tersebut ada tiga nama besar dibelakangnya yang menjadi daya kuat masing-masing paslon terutama untuk menjajaki Pemilihan Presiden 2019, ketiga nama itu ialah Megawati Soekarno Putri yang mendukung pasangan Basuki - Djarot, Prabowo Subianto yang mendukung Anies - Sandi dan yang terakhir Susilo Bambang Yudhoyono yang mendukung Agus - Sylvi.

Sejak dulu, bobot Pemilihan Gubernur DKI Jakarta selalu jauh di atas pilgub provinsi lainnya di tanah air. Apalagi setelah Presiden Joko Widodo mencatatkan sejarah bahwa beliau menapak tangga selaku Gubernur Jakarta sebelum menjadi presiden, maka harga politik gubernur ibukota negara makin naik tajam. Maka, wajar jika Pilgub Jakarta 2017 menjadi tolak ukur kemana dan bagaimana pertarungan politik pilpres 2019.

Tentu banyak faktor lain yang mempengaruhi meroketnya nilai Pilgub Jakarta. Faktor ibukota negara tidak terbantahkan menyebabkan Jakarta selalu menjadi magnet lebih. Itu sebabnya, pada Pilgub 2012, kepala daerah dari Sumatera Selatan dan Solo memilih ikut bertarung di Jakarta. Bahkan, mantan Ketua MPR Hidayat Nur Wahid rela turun gelanggang, serta ekonom tenar Faisal Basri juga ikut bertanding. Faktor lain, pusat politik dan ekonomi Indonesia memang berpusat di Jawa, tetapi episentrum utamanya tentu tetap di Jakarta. 
Maka, meskipun Jakarta adalah miniatur persoalan bangsa yang tentu lebih menantang bagi siapapun gubernurnya, tetap saja Pilgub Jakarta menjadi daya tarik lebih bagi siapapun yang ingin beradu nasib tentu dengan berbagai niatan dan maksud politik masing-masing. Salah satu niatan politik yang munculsejak suksesnya karir politik Presiden Jokowi, Gubernur Jakarta adalah tangga politik untuk naik ke kursi Presiden Indonesia. Itu sebabnya, Pilgub Jakarta 2017 menjadi seakan-akan berasa sebagai pertarungan pemanasan Pilpres 2019. Paling tidak, ada hitunghitungan Pilpres 2019, yang ikut mempengaruhi kalkulasi penentuan koalisi dan calon gubernur Jakarta 2017. (Website Detik News)

Seyogyanya Pemilihan Kepala Daerah (Pilkada) secara langsung itu dalam rangka menjaring orang yang potensial untuk memimpin. Pemimpin diharapkan lahir dan didukung oleh rakyat. Sebab pemimpin itu hakikatnya adalah cermin dari rakyat yang dipimpinnya. Pilkada di tahun 2017 ini seakan hanya Jakarta sehingga perhatian publik hanya kepada Jakarta. Bahkan Pilkada Jakarta melebihi rasa Pilpres.(Website Tribun News)

\section{Faktor Kampanye}

Kampanye merupakan tindakan komunikasi yang terencana dengan tujuan menciptakan efek tertentu pada sejumlah besar khalayak yang dilakukan secara berkelanjutan pada kurun waktu tertentu. Strategi kampanye pemilu merupakan persoalan yang sangat penting karena strategi kampanye menjadi bagian terpenting dari rangkaian kegiatan pemilihan.(Heryanto Gun Gun, $2011: 21$ )

Kampanye di DKI Jakarta dimulai dari tanggal 28 Oktober 2016 sampai dengan 11 Februari 2017. Dimulai dari menyerahkan dana kanpanye kepada KPU Provinsi DKI Jakarta.Pasangan Agus Harimurti Yudhoyono dan Sylviana Murni melaporkan dana kampanye yaitu ada di kisaran 68 Milyar Rupiah. Penerimaan dana kampanye paslon tersebut sebesar Rp 68.967.750.000dan Pengeluaran sebesar Rp 68.953.462.051.

Sekitar $42 \%$ pengeluaran terpakai untuk pertemuan tatap muka khusus terbatas ataupun pertemuan umum. Sebanyak $24 \%$ untuk peraga, spanduk, 
dan kaus, atau Rp 16 miliar. Biaya operasi mingguan Rp 3,5 miliar. Ada pula duit yang sudah dianggarkan untuk saksi di setiap tempat pemungutan suara (TPS).Pasangan Basuki - Djarot melaporkan dana kampanye yaitu Penerimaan dana paslon tersebut kampanye sebesar Rp 60.190.360.025.dan Pengeluaran sebesar Rp 53.696.961.113.

Sebelumnya, bendahara timses Ahok-Djarot, Charles Honoris, menjelaskan total penerimaan sebesar Rp 60 miliar itu terdiri dari Rp 1 juta dari pasangan calon sendiri, Rp 42,9 miliar dari sumbangan perseorangan, dan sumbangan badan hukum swasta sebanyak Rp 15 miliar. Ada pula sumbangan sebesar Rp 1,7 miliar yang belum lengkap syaratnya serta bunga bank. Sebesar Rp 1,7 miliar ini akan dikonsultasikan dengan auditor. Bila tak jelas juga, akan dikembalikan kepada negara.

Kegiatan operasional selama masa kampanye menjadi sumber pengeluaran paling besar pasangan nomor urut 2 ini. Penyebaran bahan kampanye kepada umum menyumbang pengeluaran dengan total Rp 24,5 miliar, diikuti biaya pertemuan terbatas $\mathrm{Rp} 9,2$ miliar, pertemuan tatap muka $\operatorname{Rp~7,3~miliar,~rapat~umum~Rp~5,3~miliar,~dan~lain-lain.~}$

Dan yang terakhir pasangan Anies - Sandi yang melaporkan dana kampanye yaitu sekitar 65 Milyar Rupiah. Penerimaan dana kampanye paslon tersebut adalah sebesar Rp 65.272.954.163,00 dan Pengeluarannya sebesar Rp 64.719.656.703,00. Dana kampanye tersebut berasal dari harta pribadi Sandiaga Uno dan sisanya dari partai pengusung, yakni Gerindra dan PKS, Anies, hibah badan hukum swasta, serta bunga bank. Rinciannya, sumbangan dari pasangan calon sebanyak Rp 63,3 miliar, dari gabungan partai sebesar Rp 1,1 miliar, dan sumbangan pihak lain badan hukum swasta sebesar Rp 900 juta.

Dari pengeluaran itu, biaya penyebaran bahan kampanye memakan Rp 19,2 miliar atau 30\% dari total anggaran, kegiatan yang tidak melanggar telah menghabiskan Rp 19 miliar, pertemuan tatap muka Rp 11,7 miliar, rapat umum $\mathrm{Rp}$ 6,5 miliar, pengeluaran operasional $\mathrm{Rp} 2,9$ miliar, 
pertemuan terbatas $\mathrm{Rp} 2,3$ miliar, pembelian peralatan $\mathrm{Rp}$ 1,3 miliar, pembuatan iklan media Rp 615 juta, dan alat peraga Rp 426 juta.

Dalam kampanye Pilkada DKI 2017, ditemukan masih adanya Kampanya Hitam atau Black Campaign. KPU DKI Jakarta mengungkapkan masih banyaknya kampanye hitam dalam putaran kedua Pemilihan Kepala Daerah (Pilkada) DKI Jakarta. Menurut anggota KPU, seharusnya tiap pendukung pasangan calon lebih intens ke arah adu program dibandingkan kampanye hitam. Menurutnya lagi kampanye yang baik adalah yang tidak mengaitkan isu SARA. Kampanye putaran kedua seharusnya lebih menerangkan langkah-langkah konkret yang akan diambil oleh tiap pasangan calon. Tapi menurutnya Kampanye hitam ini bisa menguntungkan masyarakat karena akan menambah informasi soal pasangan calon. Masyarakat juga memiliki akses untuk mengetahui kelebihan dan kekurangan dari program kandidat melalui kacamata lawan politik.

\section{Faktor Debat Terbuka}

Debat cagub-cawagub ini merupakan debat resmi pertama yang digelar oleh KPU DKI Jakarta. Meskipun sebelumnya para calon pernah berdebat di beberapa televisi swasta. Rencananya, debat cagub-cawagub DKI Jakarta berlangsung dalam tiga putaran. Debat pertama akan digelar pada 13 Januari, debat kedua pada 27 Januari, dan debat putaran terakhir pada 10 Februari.

Debat paslon cagub dan cawagub DKI akan disiarkan langsung oleh 10 stasiun televisi nasional. Adapun stasiun televisi yang menayangkan debat paslon Pilkada DKI Jakarta adalah TvOne, NET tv, Jawapos tv, Metro tv, MNC, TVRI, Trans group, SCTV, Kompas tv dan Jak tv.

Debat paslon Cagub-Cawagub akan digelar selama 90 menit. Materi yang disampaikan akan berkutat pada pemaparan visi - misi paslon dan pertanyaan moderator terhadap visi-misi ketiga paslon. Dari debat terbuka ini, masyarakat diminta untuk melihat program serta visi dan misi pasangan calon dari yang mereka dukung. 
Calon gubernur DKI Jakarta, Agus Harimurti Yudhoyono mengaku menyiapkan strategi khusus untuk menghadapi saingannya, terutama pejawat Ahok-Djarot. Ia mengatakan telah mempelajari kinerja AhokDjarot selama ini. Sedangkan calon Gubernur DKI Jakarta nomor urut dua, Basuki Tjahja Purnama (Ahok) percaya diri menghadapi debat cagubcawagub. Ia mengatakan telah belajar dua debat sebelumnya sehingga merasa lebih siap. Sementara pasangan nomor urut tiga, Anies BaswedanSandiaga Uno akan berbagi tema dalam menjawab pertanyaan. Ini dilakukan agar masing-masing di antara mereka mampu memaparkan gagasannya dengan baik. (Website Republika)

KPU DKI optimistis tingkat partisipasi pemilih akan naik setelah pelaksanaan debat Pilkada. Diharapkan debat sebanyak tiga kali itu dapat memberikan gambaran bagi masyarakat terkait program dan kapasitas masing-masing pasangan calon.

Berdasarkan hasil survei berbagai lembaga, tingkat partisipasi masyarakat meningkat pascapelaksanaan debat publik. Karena itu dirinya optimistis pelaksanaan debat berpengaruh signifikan bagi partisipasi politik masyarakat Jakarta. Karena berdasarkan hasil survei berbagai lembaga, tingkat partisipasi masyarakat meningkat pasca mpelaksanaan debat publik. Karena itu dirinya optimistis pelaksanaan debat berpengaruh signifikan bagi partisipasi politik masyarakat Jakarta.

\section{Faktor Media}

Media massa merupakan sarana penyampaian komunikasi dan informasi yang melakukan penyebaran informasi secara massal dan dapat diakses oleh masyarakat secara luasi Tamburaka, $2012: 21$ )

Media merupakan lembaga yang bertanggung jawab memberikan pengawasan terhadap penyelenggaraan pemilu yang bersih, jujur, adil, transparan, dan profesional. Melalui pemberitaan yang dilakukan oleh media massa, masyarakat akan memperoleh gambaran umum terkait penyelenggaraan pilkada. Termasuk menginformasikan rekam jejak caloncalon gubernur dan wakil gubernur DKI Jakarta. 
Komisi Pemilihan Umum DKI Jakarta sudah menandatangani nota kesepahaman dengan semua stasiun televisi nasional terkait sosialisasi Pilkada DKI Jakarta 2017. Anggota KPU DKI Dahlia Umar mengatakan perjanjian kerja sama itu juga mencantumkan perjanjian semua stasiun televisi berimbang dalam memberitakan pasangan cagub dan cawagub DKI.

Komisi Pemilihan Umum Provinsi DKI Jakarta tidak mengatur media massa, KPU hanya ingin ada keseimbangan sosialisasi bagi pasangan calon gubernur dan wakil gubernur di DKI Jakarta.KPU DKI akan membiayai kampanye semua pasangan calon termasuk dalam hal beriklan di media massa. Semua pasangan calon mendapatkan porsi beriklan yang sama.

\section{Penutup}

\section{A. Kesimpulan}

Peran Komisi Pemilihan Umum Provinsi DKI Jakarta dirasa cukup efektif. Komisi Pemilihan Umum Provinsi DKI Jakarta telah bekerja keras untuk meningkatkan partisipasi jumlah pemilih setiap perhelatan Pilkada yang berlangsung di DKI Jakarta terutama Pilkada serentak 2017. Mengingat data data laporan Komisi Pemilihan Umum Provinsi DKI Jakarta yang menyebutkan jumlah pemilih meningkat drastis dari pada Pilkada sebelumnya. Komisi Pemilihan Umum Provinsi DKI Jakarta sudah berupaya semaksimal mungkin untuk meningkatkan partisipasi pemilih masyarakat. Upaya-upaya yang dilakukan oleh Komisi Pemilihan Umum Provinsi DKI Jakarta dalam meningkatkan Partisipasi masyarakat dalam Pemilihan Umum Kepala Daerah DKI Jakarta 2017 yaitu :

(a) Melakukan Sosialisasi Kepada Masyarakat

(b) Menyebarkan Informasi Melalui Alat-alat Peraga (Seperti Spanduk, banner, baliho, billboard/videotron dan umbul-umbul)

(c) Sosialisasi melalui Media Massa (media cetak, media elektronik:Radio, Televisi dan/atau media dalam jaringan atau online)

(d) Komunikasi Tatap Muka 


\section{B. Saran}

1. Pihak Komisi Pemilihan Umum Provinsi DKI Jakarta diharapkan untuk lebih gencar lagi dalam melakukan sosialisasi kepada masyarakat dan jangan puas diri dahulu dengan angka partisipasi pemilih di DKI Jakarta yang mencapai Angka 77\%.

2. Masyarakat diharapkan untuk lebih sering mengikuti informasi baik dari media massa atau mengikuti sosialisasi yang diadakan oleh Komisi Pemilihan Umum Provinsi DKI Jakarta. Agar tumbuh kesadaran akan pentingnya mengikuti Pemilihan Umum Kepala Daerah DKI Jakarta.

\section{Daftar Pustaka}

Budiardjo, Miriam. Dasar-dasar Ilmu Politik, Jakarta:Gramedia, 2008.

Fadjar, Mukthie. Pemilu, Perselisihan Hasil Pemilu dan Demokrasi. Malang: Setara Press, 2013.

Gun Gun, Heryanto. Dinamika Komunikasi Politik. Jakarta: Lasswell Visitama, 2011.

Johan, Teuku Saiful Bahri. Hukum Tata Negara Dan Hukum Administrasi Negara. Cetakan Pertama. Yogjakarta: Deeppublish, 2018.

Mas'oed, Mochtar dan Mac Andrews. Perbandingan Sistem Politik. (Yogjakarta:Gajah Mada University Press. 2000). Hlm 225

Prihatmoko, J. Joko,. Pemilu 2004 dan Konsolidasi Demokrasi. Semarang: LP2I Press. 2003.

Pusat Bahasa, Kamus Besar Bahasa Indonesia, Gramedia Pustaka Utama, Jakarta,1997.

Sanit, Arbi. Partai, Pemilu dan Demokrasi. cetakan pertama. Yogyakarta: Pustaka Pelajar, 1997.

Sudijono,Sastroatmodjo. Perilaku Politik. Semarang : Ikip Semarang Press. 1955.

Tamburaka, Apriadi. Agenda Setting, 2012. 
Yusuf, Peran Komisi Pemilihan Umum Dalam Pendidikan Politik, Universitas Mataram: Sebuah Karya ilmiah, 2010.

Indonesia. Undang-Undang Dasar Negara Republik Indonesia tahun 1945. . Undang-Undang Republik Indonesa Nomor 7 Tahun 2017 tentang Pemilihan Umum

_. Undang Undang Nomor 1 Tahun 2015 tentang Pilkada . Undang Undang RI Nomor 15 Tahun 2011 Tentang Penyelenggara Pemilu . Undang-Undang Nomor 22 Tahun 1999 tentang Pemerintahan Daerah

- Undang-Undang Nomor 22 Tahun 2014 Tentang Pemilihan Gubernur, Bupati dan Walikota Peraturan KPU Nomor 4 Tahun 2017 Tentang Kampanye . Keputusan KPU Provinsi DKI Jakarta Nomor : 22/kpts/KPU-Prov010/Tahun2016

Wawancara media Kompas TV kepada anggota KPU Provinsi DKI Jakarta Wawancara Komisioner KPU DKI Jakarta dalam wawancara kepada Media Website Detik Com. https://news.detik.com/ Diakses tanggal 22 Juli 2018 pukul 18:17 WIB

Website Detik Finance. "Sandiaga Uno Merasa Tak Penting Masuk Daftar Terkaya Forbes"http://www.detikfinance.com. Diakses 27 Juli 2018 pukul 17:55 WIB

Website KPU. https://pilkada2017.kpu.go.id/hasil/2/t1/dki_jakartaDiakses Pada tanggal 8 Mei 2018, Pukul 15:12 WIB

Website Republika. https://www.republika.co.id/ Diakses tanggal 27 Juli 2018 pukul 21:39 WIB

Website Tribun News. http://www.tribunnews.com/ Diakses tanggal 27 Juli 2018 Pukul 18:22 WIB

Website Wikipedia. https://id.wikipedia.org/, Diakses tanggal 27 Juli 2017, pukul 17:21 WIB 